\title{
The Test Stand Load Modulus Implementation for the Realistic Railway Operation in the La- boratory Conditions
}

Juraj Gerlici, Tomáš Lack, Jozef Harušinec

University of Žilina, Faculty of Mechanical Engineering, Department of Transport and Handling Machines, Univerzitná 1, 010 26, Žilina, tel.: +421 (41) 513 2693,2550, 2652, e-mail: juraj.gerlici@ fstroj.uniza.sk.

The aim of the article is to present the necessity of completion of the test stand of brake components of railway vehicles with the equivalent railway operation load simulator for the research of the wheel wear on it. The other aim of presented research needs is to perform the analysis of the equivalent conicity as a parameter for the rail vehicles in operation ride properties prediction. The sub aims are the change of frame, wheel, braking forces load via SIMRAIL simulator program load collection performance.

Keywords: test stand, railway operation, laboratory conditions, wheel tread wear, equivalent conicity

\section{Acknowledgement}

The work was supported by the Scientific Grant Agency of the Ministry of Education of the Slovak Republic and the Slovak Academy of Sciences in project No. 1/1098/11: "Stress Distribution in a Braked Railway Wheel". No. 1/0347/12: "Railway wheel tread profile wear research under the rail vehicle in operation conditions simulation on the test bench", project No. 1/0383/12: "The rail vehicle running properties research with the help of a computer simulation." and the project No. APVV-0842-11: "Equivalent railway operation load simulator on the roller rig". Research-Educational Center of Rail Vehicles (VVCKV)

\section{References}

[1] GERLICI J., LACK T., HARUŠINEC J. (2013) SIMRAIL - the Load Modulus of the Test Stand for the Realistic Simulation of Railway Operation in Laboratory Conditions. In: Proceedings of the Conference: Dynamics of Rigid and Deformable Bodies 2013, ISBN 978-80-7414-607-7, CD-ROM, Ústí nad Labem, FVTM UJEP, (p.8).

[2] GERLICI J., LACK T., HARUŠINEC J. (2013) Test Bench Modulus Construction Proposal for the Realistic simulation of Railway Operation. In: Proceedings of XXXIX International Conference of the Transport, Handling, Civil and Agricultural machines, ISBN 978-80-248-3124-4. CD-ROM, Ostrava: ID FS VSB - TU Ostrava, (p.5).

[3] ŠTEFAŇAKOVÁ, V., GERLICI J., LACK T., HARUŠINEC J. (2013) Test Stand Load Modulus Construction Proposal for the Realistic Simulation of Railway Operation. In: Proceedings of TRANSCOM 2013: 10-th European Conference of Young Researchers and Sientists, ISBN 978-80-554-0695-4. University of Žilina. (p.305-308).

[4] GERLICI J., LACK T., HARUŠINEC J., MÜLLER R., DOLEŽEL P. (2011) RAILBCOT Rail Vehicles Brake Components Test Stand, Proceedings PRORAIL 2011 Žilina, Scientific and Technical Society at the University of Žilina, 2011, (p.233241).

[5] GERLICI J., LACK T., HARUŠINEC J. (2012) RAILBCOT = Laboratory Test Bench for Railway Wheelset Wheels Tread Wear Analysis - RAILBCOT. In: Proceedings of SETRAS 2012, ISBN 978-80-89276-39-4, Žilina, Scientific and Technical Society at the University of Žilina, in Slovak, (p. 31-41).

[6] GERLICI J., LACK T., HARUŠINEC J. (2012) Test Stand Properties Analysis for Wheel-tread Wear in Accordance with the Laboratory Simulated Railway Operation. In: Proceedings of VSDIA 2012: 13th Mini conference on Vehicle System Dynamics, Identification and Anomalies 2012, Abstracts. Budapest 2012, (p.9).

[7] KALIVODA J., BAUER, P. (2012) Roller Rig Implementation of Active Wheelset Steering, In: Proceedings of the First International Conference on Railway Technology: Research, Development and Maintenance. Stirling: Civil-Comp Press Ltd, ISBN 978-1-905088-52-2vol. 1, (p.1-13).

[8] GERLICI J., LACK T. (2011) Railway Wheel and Rail Head Profiles Development Based on the Geometric Characteristics Shapes. Wear Vol. 271, No. 1-2 Sp. iss. (2011), (p.246-258).

[9] GERLICI J., LACK T. (2009) Railway Wheel Profile Development Based on the Geometric Characteristics Shapes, Proceedings of Contact mechanics and wear of rail/wheel systems, Firenze, Italy. - Firenze: AB EDITORE, (p.961-967).

[10] GERLICI J., LACK T. (2010) Contact Geometry Influence on the Rail / Wheel Surface Stress Distribution, Procedia Engineering Vol. 2, iss. 1 2010, (p.2249-2257).

[11] GERLICI J., LACK T. (2008) Rail Roughness and Railway Wheel Unroundness Analysis, Proceedings of XVIII konferencja naukowa - pojazdy szynowe: Katowice-Ustroń, (308-318).

[12] GERLICI J., LACK T. (2009) Iterative Method for Railway Wheel Profile Design, Communications- Scientific Letters of the University of Žilina, Vol. 11, No. 2 2009, (p.49-56). 